\title{
USE OF NUMBERED HEAD TOGETHER MODEL IN INCREASING ISLAMIC EDUCATION LEARNING INTERESTSTUDENTS IN CLASS VII SMPN 07 NORTH BENGKULU
}

\author{
Basinun \\ Institut Aagama Islam Negeri Bengkulu \\ Email: basinuniainbengkulu@.ac.id
}

\begin{abstract}
Problem identification of this research is 1. Still low student interest which caused by Lack of attention of student to learning of PAI especially in subject matter closer to Allah SWT. Its very beautiful name, like students often joking, often daydreaming and students often out of the classroom. 2. the method used is always monoton that the teacher always use the lecture method, so that students feel bored in teaching and learning process (PBM). The approach used in this is a classroom action research, which will be carried out through a few steps until the research is successful. The results obtained on the prasiklus step the number of values obtained is 453 with the result of the average value of 17.42 with $43.55 \%$ percentage, from the observation proves that the lack of interest in learning students in learning PAI especially the subject matter closer to the god SWT. The very beautiful name with the value category is still low, because the value obtained in the observation is still below the KKM. Because the value obtained is low, therefore the next step needs to be done, so that the results achieved can be maximized.The next step is cycle I with the total value of 591 with the result of the average value of 22,73 result of the percentage of $56,82 \%$ from result of observation prove that student have interest but student interest of student have not show in full, and value obtained in observation still below KKM . Because the results obtained are still not maximal then need to re-implement the next step, so that the results achieved can be maximized. The second step of cycle II with the total value of 731 and the results of the average value of 28.11 with the percentage of $70.27 \%$, And the results of students already interested but the student's learning interest has not shown fully, given the value obtained in the observation is still less and still below KKM. Therefore, it is necessary to implement the next step, so that the results achieved can be maximized. Step cycle III the number of values obtained is 837 with an average value of 32.19 and the percentage is $80.47 \%$. From the observations made through the observation sheet proves that in the step of cycle III students already seen if they are very interested in learning and the value obtained is already above the minimum completeness criteria (KKM) that have been determined. Because the results obtained are satisfactory, the action research is stopped, just until the third cycle. From the results of the above research proves that by using NHT method can increase student learning interest in learning PAI.
\end{abstract}

\section{Introduction}

Islamic religious education is a conscious and well-planned effort in preparing learners to know, understand, live, believe, cultivate noble morals, practice the teachings of Islam from the main source of the holy kites of Al-Quran and Hadith, through guidance activities, teaching exercises as well as the use of experience. ${ }^{1}$

Education is a process in order to influence students in order to adapt as well as possible to their environment and thus will create a change in him

'Ramayulis, Metodologi Pendidikan Agama Islam(Jakarta:Kalam Mulia 2010) h.21

44

NUANSA Vol. XI, No. 1, Juni 2018 that enables him to function strongly in the life of society. $^{2}$

In essence teaching and learning activities is a process of interaction or mutual relationships between teachers and students in a lesson. Teachers as one component in teaching and learning process is a very important role holder. Teachers are not just transmitters of material, but more than that the teacher can be said as a central learning.

As a regulator and also in the process of teaching and learning, the teacher guides how the teaching and learning process is implemented. Therefore, h. 79

${ }^{2}$ Oemar Hamalik, Proses Belajar Mengajar(Jakarta: Bumi Aksara, 2001) 
teachers should be able to make a lesson to be more effective as well as interesting so that the learning materials that are delivered will make students feel happy and feel the need to learn the lesson material. For that required an activity undertaken by teachers with efforts to arouse students' interest in learning, for example by guiding students to engage directly in activities involving students as well as teachers who act as mentors to discover the concept of PAI. As well as teachers should be able to understand that the use of appropriate and varied models will be used as a tool of extrinsic motivation in teaching and learning activities in schools. ${ }^{3}$

Based on the observations of researchers at SMPN 07 North Bengkulu there are some obstacles encountered in the process of Learning Islamic Religious Education is that students pay less attention to the material delivered because of the emergence of boredom with a model of conventional monotonous learning, students do not like subjects Islamic Religious Education because assume that the subjects Islamic education is a difficult subject to understand and many Arabic writings. Of these factors resulted in the mastery charged to the students become less able to achieve.

One of the lessons taught in SMPN 07 Bengkulu Utara is Islamic Religious Education (PAI). PAI is one of education that is very important for life especially for Muslim, because Islamic education is education with through the teachings of Islam that is some guidance and upbringing to students, so that later after completion of education, students can understand, live, and practice teachings of Islam as a view of his life for the salvation and welfare of life in the world and in the hereafter.

\section{Discussion}

As an educator or teacher teachers should be able to create the atmosphere and conditions of learning the best by using various models so that students can achieve maximum learning results. In perosespelelajaran model has a very important position in the effort to achieve goals, because the model is a way or path that is appropriate and harmonious to present a thing so that will be achieved an effec-

${ }^{3}$ Syaiful Bahri Djamarah, M.Ag. Aswan Zain, Strategi Belajar Mengajar, (PT Rineka Cipta,Jakarta,2010)h.73 tive and efficient learning objectives as expected.

In the learning process found a lot of learning, one of them is a Numbered Head Together, this model is a way of teaching with numbering berfikir. Pendidikan Islam is intended to increase the spiritual potential and form learners to be a man who believes and cautious to God Almighty and morality. Indonesian religious education is expected to produce people who always perfect the faith and piety and actively build civilization and harmony of life.

The cooprative model of type (NHT) is chosen because it allows the student to be more active in the learning process by communicating the results of the discussion with the group. Winarni states that the Numbered Head Together (NHT) or shared numbering is a structural cooprative learning developed by Spencer Kagen . This model emphasizes the use of specific structures designed to influence the pattern of student interaction as an alternative to traditional classroom structures. ${ }^{4}$

With this NHT model can be more involving students, because with the teacher mentions the number held, allowing them to deliver the results of the discussions that have been done. Each student can express his opinion all after the number held mentioned teacher. Then when the students have finished expressing their opinions, teachers can provide reinforcement to students who have answered it to appreciate their efforts.

Something learning activities will work if the students can receive the learning materials well by looking at the test results after the students finished studying. Therefore, the influence of learning interest of PAI students through NHT model is expected to overcome the problems that exist in the process of learning activities in special schools in class VII B SMPN 07 North Bengkulu.

Based on the results of interviews with teachers of Islamic religious education subjects above on the pre cycle obtained some information thatthe use of coeducation type learning Numbered Head Together has never been used in peroses pengajar the Islamic Religious Education in class VII SMPN 07, while the students' learning ability of Islamic Education Learning is still very low. Based on the num-

${ }^{4}$ Winarni, Endang Widi.Inovasi dalam Pembelajaran IPA. Skripsi Wahyu Hidayat. (Bengkulu :UNIB.,2012). 
46 遥 NUANSA Vol. XI, No. 1, Juni 2018

ber of data obtained, the number of students of class VIIB is 26 students consisting of 13 male students and 13 female students.

The researcher also convey that the research will be done in several cycles, if on sisklus I researchers have not seen the increase in student learning outcomes then students can not be said to have high learning interest. So every end of each cycle will be tested at the end of the action to know and measure how far the students are doing.

Researchers convey that will act as the executor of acts and acts as observers are the researchers themselves. And the researchers explain that the observer on duty to observe all student activities take place. To facilitate the observation, the observer will be given an observation sheet and explain how to fill it. Researchers also said that before the study using the model will be conducted early tests first.

Based on the agreement plan, the researcher conducts preliminary test (PreSiklus) to know the student's early ability to the material closer to the very beautiful god her name. Before pre-test, the researcher first introduces himself and gives a little question about the matter closer to the beautiful gods of his name to give a little picture of the material. Prior to the action and obtain preliminary results before the use of model Numbered Head Together, test results obtained to determine the interest of students learning on learning PAI is as follows :

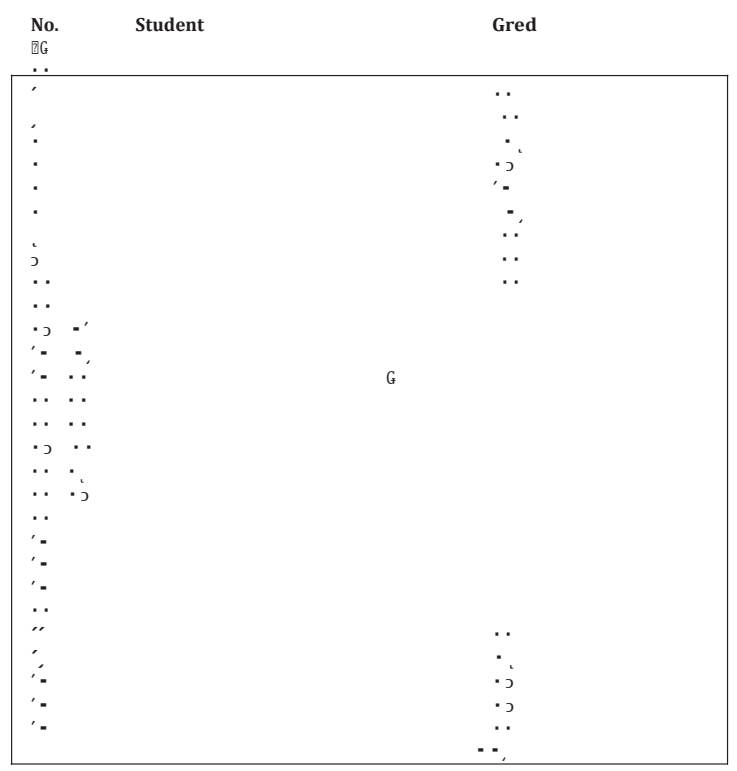

Figure 1 : Results Observation Sheet Student Learning Interest in PAI Learning Basic Subject matter closer Allah on Prasiklus Steps.
The result of observation of student learning interest of PAI learning subject matter closer to Allah is very beautiful name in step prasiklus show average value obtained that is 17,42 with result percentage $43,55 \%$. From the observations above proves that the lack of interest in student learning in learning PAI especially the subject matter closer to God is very beautiful name with the category value is still low, because the value obtained in the observation is still below the criteria of achieving the minimum value. The assessment criteria are as follows:

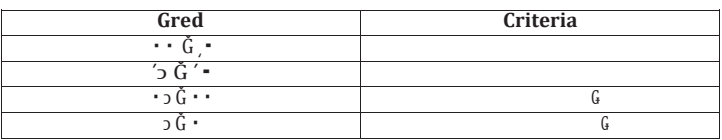

Figure 2: Assessment Criteria

From the observations made through the observation sheet shows that in this prasiklus step there are 22 students who are less interested in learning especially in learning PAI the subject matter closer to the Allah are very beautiful name, this is marked by lack of readiness of students in receiving lessons, because the lack of response so that students less dexterous or responsive in answering questions, then students are less enthusiastic in answering questions, and the last is less the feeling of interest to answer questions.

\section{Conclusion}

This research is a classroom action research, which will be carried out through several steps until the research is successful. The results obtained from the implementation of action starting from the implementation of Prasiklus, cycle I, cycle II, and last cycle III there is a positive result of each cycle. This can be evidenced by the average value of the observed sheets in each cycle. In step prasiklus the number of values obtained is 453 with the result of the average value 17.73 with the percentage of $43.55 \%$, from the results of observation proves that the lack of interest in student learning in learning PAI especially the subject matter closer to the swt gods are very beautiful name with the category of nilaimasih low, because its very beautiful name of the value obtained in the observation is still below the criteria of achieving the minimum value. Because the value obtained is low, therefore the next 
step needs to be done, so that the results achieved can be maximized.

The next step is cycle I with the total value of 591, with the result of the average value of 22,73 result of the percentage of $56,82 \%$ from result of observation proves that student have interest but the student's learning interest have not shown fully, and value obtained in observation still under the minimum value attainment criteria. Because the results obtained are still not maximal then need to re-implement the next step, so that the results achieved can be maximized.

Next step cycle II with the total value of 731 and the average value of 28.11 with the percentage of $70.27 \%$. From the results of observation of the second cycle proves that the students are interested but the students' learning interest has not shown fully, considering the value obtained in the observation is still less and still under the criteria of achieving the minimum value. Therefore, it is necessary to implement the next step, so that the results achieved can be maximized.

Step cycle III the number of values obtained is 837 with an average value of 32.19 and the percentage is $80.45 \%$. From the observations made through the observation sheet proves that in the step of cycle III students have looked when they are very interested in learning and the value obtained is above the criteria of achieving the minimum value that has been determined. Since the results obtained are quite satisfactory then the implementation of action research is stopped, simplyuntil the third cycle.

\section{Bibliography}

Al-Qur'an Dan Terjemahan. Jakarta: Depag RI

Amalik Oemar, 2001. Proses Belajar Mengajar, Jakarta : Bumi Aksara

Arief Armai, 2002. Pengantar Ilmu dan Metodologi Pendidikan Islam

Azhari Akyas, 2004. Psikologi umum dan Perkembangan, Jakarta : Teraju

Djali, 2008. Psikologi Pendidikan, PT Bumi Aksara

Djamarah Bahri Syaiful, Aswan Zain, 2010. Strategi Belajar Mengajar, PT Rineka Cipta, Jakarta

Leo Sutato, 2013. Kiat Jitu Menulis Skripsi Tesis, dan Disertasi. PT Gelora Askara Pratama

Mudjiono dan Dimyati, 2009. Pesikologi Pembelajaran . Bandung: Unesa University press

Nana Sudjana, 2006. Tumtutan Penyusunan Karya Ilmiah. Bandung : Sinar Baru Algesindo

Ramayulis, 2010. Metodologi Pendidikan Agama Islam Jakarta: Kalam mulia

Rusma, 2010. Model-model Pembelajaran Mengembangkan Profesionalisme Guru. Jakarta: Rajakrafindo Persada

Slameto, 2010. Belajar dan Faktor-faktor Yang Mempengaruhi. Jakarta: Rineka Cipta

Suhermi, 2000. Pembelajaran Koopratif. Surabaya: Unesa Universitas Press

Suprijino Agus, 2009. Coopratif Learning dan Teori PAIKEM. Yogyakarta: pustaka belajar

Suryabarat Sumadi, 2008. Pesikologi Pendidikan. Jakarta: PT Raja Grafindo Persada

Suyanto Agus, 2004. Psikologi Umum. Jakarta: Bumi Aksa

Syah Muhibbin, 2007. Psikologi Belajar. Jakarta : PT Raja Grafindo Persada 
